\title{
Acarology in Egypt: A Brief History
}

\author{
M. A. Zaher \\ Emeritus Prof., Faculty of Agric., Cairo University, Giza, Egypt
}

It is of great pleasure to give a brief account on the "History of Acarology in Egypt" in the $1^{\text {st }}$ issue of "Acarines", the journal of the Egyptian Society of Acarology.

The occurrence of Acari in Egypt was known as early as time of ancient Egyptians, thousands of years ago. A reference to "tick fever" was recorded on papurus scroll on the $16^{\text {th }}$ century B.C. (Krantz 1978). Also Arthur (1965), examined a drawing of hyena-like animal from the time of Queen Hatshepsut III in the $15^{\text {th }}$ century B.C. and considered the three exrescences in its ear to represent three ticks.

Nothing was recorded after that till the $18^{\text {th }}$ century, when Linnaeus (1776) recorded in the $10^{\text {th }}$ edition of "Systema Naturae" fewer than 30 acari species. Of these, an Egyptian hard tick was named Acarus eagyptius which after that changed to Hyalomma aegyptium. Later, at the end of the $18^{\text {th }}$ century and beginning of $19^{\text {th }}$ century (1798-1801), during the French Military Mission in Egypt, Savigny, a member of the scientific mission collected and made drawings of 10 acari, mainly ticks which were identified by Audouin in 1827 and revised by Marc Andree to represent less than 10 of tick species.

In 1901, Ivar Tragardh, a member of the Sweden Scientific Mission to Egypt and the Sudan collected and described some Acari species which he included in his book in 1905.

In 1918 and 1919 a \& b, Debski referred to some eriophyid mites in his papers on plant galls and causes, but could not identify the mite species.

Willcocks (1916, 1922 \& 1925), belonging to the Royal Agricultural Society founded in 1898 in Egypt reported the incidence of some important mites. He referred to a report by the horticulture inspector of the Barrage area in 1904 about the increase of the spider mite on lebbek trees (Albizzia lebbek) in Upper Egypt.

Also, Willcocks \& Bahgat (1973) reported the occurrence of some mite species. These were Pediculoides ventricaus, (1916) and hypopus of Rhizoglyphus echinopus, (1937) associated with resting larvae of the cotton pink bollworm. They also mentioned the occurrence of the spider mite Tetranychus bimaculatus (due to its obvious eyes) and reported that more than one strain or species existed as well as other tetranychids and unidentified predatory mites.

A real contribution of Egyptian acarologists began in $1930^{\text {th }}$ by the two pioneers Hassan and Sayed. Upon his return from California, USA, in 1928 where he got his Ph.D. in Acarology (Eriophyidae), the former started work in the Ministry of Agriculture for few years, then moved to the Faculty of Agriculture, Cairo University. He drew attention to inspection of fruit trees in nurseries and imported seedlings and cuttings for mite infestation. In 1934, he recorded the occurrence of four eriophyid species infesting pear, fig, tomato and 
olive causing leaf blisters, leaf russeting, stem and leaf white appearance due to numerous plant hairs grown abnormally through tissue irritation, and leaf-curls respectively. In 1944 he was the first to record Eriophyes mangiferae sp. $\mathrm{n}$. infesting mango trees in Sharkia governorate, but unfortunately did not give any description of this new species. In 1952-1958, he suprevised 3 M.Sc. theses on biology, ecology and control of tetranychid and eriophyid mites publishing five papers in 1956 \& 1959. On the other hand, during nearly the same period (1936-1952) Sayed, who got his Ph.D. from London University (1936) and working in the Ministry of Agriculture, established a branch of Acarology at Entomology Department. He actually did excellent work as he described several new species of the families Tetranychidae, Tenuipalpidae and Eriophyidae (Sayed 1938; 1940; 1942 a, b, c \& d; 1946 a, b, c, d \& e; 1950 a \& b). He created some tenuipalpid genera, a subfamily and proposed the name Tenuipalpidae for the family. In mid 1950, he moved to be head the Department of Entomology, Faculty of Science, Ain Shams University.

Following the work of the two pioneers, Hassan and Sayed, one can think of later developments as build up of a pyramid of acarologists.

In 1959, Zaher established a special curriculum in Acarology for postgraduate students to be in fulfillment of M.Sc. and Ph.D. degrees in Acarology at the Faculty of Agriculture, Cairo University. Thus, most of Ph. D.'s in Acarology here at present are graduates of this school of Acarology supervised by Zaher, and later from schools at different universities and research centers. In the meanwhile, Attiah (1956-2000) of the Ministry of Agriculture carried out important work on taxonomy, ecology and control of phytophagous mites.

Also, El-Badry (1965-1980) undertook good research work on mite taxonomy, biology and ecology at the Faculty of Agriculture, Ain Shams University.

The discovery of mite founa in Egypt (more than 700 species) was mainly obtained through M. Sc's and Ph.D.'s theses together with an Egyptian-American project on phytophagous, predaceous and soil mites allover the country (1976-1984) directed by Zaher. Concerning ticks, Hoogostral (1955-1985) of the United States Navey Medical Research (Namru3) in Cairo did important research work and established a school of tick research in cooperation with Egyptian Universities. After that, Kammah is leading tick research in the Faculty of Agriculture, Cairo University.

It can be stated that the diversity of habitats, moderate, climate and evergreen agricultural system in Egypt lead to believe that hundreds of mite species are still undiscovered despite the noticeable discovery of mite fauna during the $2^{\text {nd }}$ half of the $20^{\text {th }}$ century.

Finally, at present, acari research work spread in all Egyptian Universities, National Research Center and Agricultural Research Center. Moreover, farmers are now aware of Acari problems and how to face it. Hope progress of Acari research work will continue in future. 


\section{REFERENCES}

Andre', M., 1935. Les acarines figues per Savigny dans la description de 1'Egypte. Bull. Mus. Hist. Nat., Paris, S. z., 7 (3): 197-200.

Arthur, D. R., 1965. Ticks in Egypt. In 1500 B. C. (Letter to editor). Nature, London (4988), 206: 10601061.

Audouin, J. V., 1827. Description de L'Egy-pte, ou recueil de observations del'ar-mee francaise, publie per les ordres de sa majeste l'empereur Napelleon le Grand. Zoologie, Ed. 2, 22.

Debski, B., 1918. Liste des cecidies signalee's en Egypte Jusqu'a jour. Mem. Soc. Ent. Egypte, 1 Fasc. 4:19.

Debski, B., 1919a. Description de trios ceci-dies nouvelles et quelques remarques sur d'autres cecides d'Egypte. Bull. Soc. Roy. Ent. Egypte', 30.

Debski, B., 1919b. Novelles additions a ma liste de cecidies d'Egypte. Bull. Soc. Roy. Ent. Egypte, 68.

Hassan, A. S., 1928. Biology of the Erioph-yidae. Univ. California. Publ. Ent. 4: 394 pp.

Hassan A. S., 1934. Notes on the Eriophyidae of Egypt (Acarina); Bull. Soc. R: ent. D'Egypte, 18: 440-444.

Hassan, A. S., 1944. Notes on Eriophyes mangiferae sp. N. (Acarina). Bull. Soc. Fouad 1er Entomol., 28:179-182.

Hassan, A. S. and Zaher, M. A., 1956. Biology of the red spider mite Eotetranychus cucurbitacearum Sayed. Bull. Soc. Ent. Egypte, 40: 301-320.

Hassan, A. S. El-Nhal, A. K. M. and El-Badry, E. A., 1959. Infestation of cotton with spider mites (Acarina)

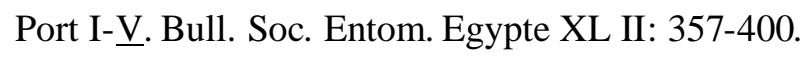

Krantz, G. W., 1978. A manual of Acarology. Oregon Sta. Univ. Book Stores, Ine. Corvallis, 509 pp.

Sayed, M. T., 1938. Sur une novelle sous-famille et deux neuveau generes de Tetranyques (Acarina). Bull. Mus. Nat. Hist. Paris (Sér 2), 10: 601-610.

Sayed, M. T., 1940. Sur une novelle sous-famille et deux nauveau genere de Tetranyques (Acarina). Bull. Soc. Fouad1 $1^{\text {er }}$ Entom., 24: 250.

Sayed, M. T., 1942a. Contribution to the knowledge of the Acarina of Egypt. I- The genus Raoiella Hirst (Pseudo-tetranychinae-Tetranychidae) Bull. Soc. Foued $1^{\text {er }}$ Entom., 26: 81-92.

Sayed, M. T., 1942b. Contribution to the knowledge of Acarina of Egypt. II-The genus Tenuipalpus Donnadieu. Bull. Soc. Fouad ${ }^{\text {er }}$ Entom., 26: 93-113.

Sayed, M. T., 1942c. Contribution to the knowledge of Acarina of Egypt. III- The genus Phytoptipalpus Tragardh. Bull. Soc. Fouad1 ${ }^{\text {er }}$ Entom., 26: 114-124.

Sayed, M. T., 1942d. Contribution to the knowledge of Acarina of Egypt. IV- The genus Anychus McGregor. Bull. Soc. Fouad1 ${ }^{\text {er }}$ Entom., 26: 125-131.

Sayed, M. T., 1946a. Contribution to the knowledge of Acarina of Egypt. Five new species of Tetranychidae. Bull. Soc. Fouad1 ${ }^{\text {er }}$ Entom., 30: 79-98.

Sayed, M. T., 1946b. Description of Tenui-palpus granati nev. Slpec. And Brevipalpus pyri nov. sp. Bull. Soc. Fouad $1^{\text {er }}$ Entom., 30: 98-104.

Sayed, M. T., 1946c. Three eriophyid mites from Egypt. Bull. Soc. Fouad1 ${ }^{\text {er }}$ Entom., 30: 149-164. 
Sayed, M. T., 1946d. Aceria mangiferae nov. spec. (Acarina-Eriophyidae). Bull. Soc. Fouad1 ${ }^{\text {er }}$ Entom., 30: 7-10.

Sayed, M. T., 1946e. The genus Anychus McGregor in Egypt and the Sudan. Bull. Soc. Fouad $1^{\text {er }}$ Entom., 30: 143-148.

Sayed, M. T., 1950a. Description of a new genus and two new species of the family Tenuipalpidae. Proc. $8^{\text {th }}$ Int. Cong. Ent., 1018-1021.

Sayed, M. T., 1950b. On the taxonomy of the tetranychid and allied genera; a new family and two new subfamilies in Acarina. Porc. $8^{\text {th }}$ Int. Cong. Ent., 1012-1017.

Tragardh, I., 1905. Monographie der arkitsch-en Acariden. Founa Arct. (Roemer u. Schaudinn), 4 (1): 1-78.

Willcocks, F. C., 1916. The insects and related Pests of Egypt. Vol. 1, Pt. 1. The Insects and Related Pests Injurious to the Cotton Plant. (the pink bollworm). Printing Office, French Inst. Oriental Archeology: 339 pp.

Willcocks, F. C., 1922. A survey of more important economic insects and mites of Egypt. Tech. Bull. No. 1. The Royal Agric. Soc. of Egypt.

Willcocks, F. C., 1925. Insects and mites feeding on germanous crops and products in the field, grainary \& mill. The Insect and related Pests of Egypt. Vol. II.

Willcocks, F. C. \& Bahgat, S., 1937. The Insects and Related Pests of Egypt, Vol. 1, Pt. 2. Insects and Mites Injurious to Cotton Plant, Lencioni, Cairo: 1-791. 